\title{
Application OF $\mathrm{SiO}_{2}$ NANOPARTICles as PRETREATMENT AlleViates THE IMPACT OF DROUGHT ON THE PHYSIOLOGICAL PERFORMANCE OF Prunus mahaleb (Rosaceae)
}

\author{
PEYMAN ASHKAVAND ${ }^{+1}$, MEHRDAD ZARAFSHAR ${ }^{\dagger 2}$, MASOUD TABARI $^{1}$, JAVAD $^{2}$ \\ MIRZAIE ${ }^{3}$, AMIRREZA NIKPOUR ${ }^{4}$, SEYED KAZEM BORDBAR ${ }^{2}$, DANIEL STRUVE ${ }^{5}$ and \\ GUSTAVO GABRIEL STRIKER ${ }^{6^{*}}$
}

\begin{abstract}
Summary: We studied the physiological responses of Prunus mahaleb (Mahaleb) seedlings to drought stress when previously irrigated (or not) with different concentrations of $\mathrm{SiO}_{2}$ nanoparticles (SNPs). SNPs were applied at four concentrations $(0,10,50$ and $100 \mathrm{mg} \mathrm{L}-1)$ for 45 days, and then seedlings were subjected to three watering treatments including low $(300 \mathrm{~mL}$ water every $3 \mathrm{~d})$, moderate $(150 \mathrm{~mL}$ water every $3 \mathrm{~d}$ ) and severe drought stress (no irrigation) for 19 days. Results showed that gas exchange photosynthesis, stomatal conductance, and transpiration rate - were significantly less impacted by severe drought stress when seedlings were pretreated with SNPs at high concentrations. Beneficial effects of SNPs pretreatment were evident in the nutritional status of the plants as the concentration of $N, P$ and $\mathrm{K}$, were maintained at similar levels than in well-watered seedlings. Pretreated seedlings were able to maintain the root length and to reduce the impact of severe drought on root dry mass accumulation. Therefore, application of SNPs as pretreatment should be considered as a promising agronomic practice in sites prone to suffer from water deficit.
\end{abstract}

\begin{abstract}
Key words: Pre-treatment, Silica nanoparticles, drought, stress alleviation, photosynthesis.
Resumen: La aplicación de nanoparticulas de $\mathrm{SiO}_{2}$ como pretratamiento disminuye el impacto de la sequía en la performance fisiológica de Prunus mahaleb (Rosaceae). En este trabajo se estudiaron respuestas fisiológicas de Prunus mahaleb (Mahaleb) a la sequía luego de la aplicación de diferentes concentraciones de nanoparticulas de $\mathrm{SiO}_{2}$ (SNPs) por irrigación como pretratamientos. Se aplicaron 4 concentraciones de SNPs $\left(0,10,50\right.$ and $\left.100 \mathrm{mg} \mathrm{L}^{-1}\right)$ durante 45 días y, a posteriori, las plantas fueron sujetas a tres regímenes hídricos que incluyeron control ( $300 \mathrm{~mL}$ cada 3 días), estrés hídrico moderado (150 mL cada 3 días) y estrés hídrico severo (sin riego) por 19 días. El intercambio de gases fotosíntesis, conductancia estomática y transpiración -se redujo menos frente a la sequía en las plantas que recibieron pretratamientos con SNPs. El estado nutricional de las plantas tratadas con SNPs visto por la concentración de N, P y K se mantuvo bajo sequía moderada. Las plantas pretratadas con SNPs mantuvieron el largo de sus raíces y sufrieron menor impacto en su biomasa radical ante sequía. Se concluye que la aplicación de SNPs como pretratamiento podría ser una práctica agronómica para sitios propensos a déficit hídricos en épocas cercanas a la plantación.
\end{abstract}

Palabras clave: Nanopartículas de sílice, fotosíntesis, sequía, pre-tratamiento, mitigación de estrés.

$\dagger$ These authors contributed equally to this work

${ }^{1}$ Department of Forestry, Faculty of Natural Resources and Marine Sciences, Tarbiat Modares University, Iran.

2 Department of Natural Resources, Fars Agricultural and Natural Resources Research and Education Center, AREEO, Shiraz, Fars, Iran.

${ }^{3}$ Department of Forest Sciences, Faculty of Agriculture, University of Ilam, Iran.

${ }^{4}$ Department of Forest Sciences, Gorgan University of Agricultural Sciences and Natural Resources, Iran.

${ }^{5}$ Department of Horticulture and Crop Science, 2001 Fyffe Ct, The Ohio State University, USA.

6 IFEVA, Universidad de Buenos Aires, CONICET, Facultad de Agronomía, Avenida San Martín 4453, CPA 1417, DSE Buenos Aires, Argentina. * Corresponding author e-mail: striker@agro.uba.ar 


\section{INTRODUCTION}

Drought stress, as multidimensional abiotic stress, strongly affects growth, development, and yield of plants (Mahajan \& Tuteja, 2005). Undoubtedly, understanding mechanisms that plants use to deal with drought stress are important. However, equally important are cultural methods enhancing natural drought tolerance (Sacala, 2009). Given that conventional fertilisers can have adverse effects on the environment and potentially on food quality, researchers are now investigating the potential use of nanotechnology to reduce the negative impact of abiotic stresses in plants (Asadzade et al., 2015; Chen \& Yada, 2011; Haghighi \& Pessarakli, 2013). Nanosciences have led to the development of a wide range of applications for enhancing of plant growth (Nair et al., 2010). Carbon-based, metal oxides, quantum dots, nano-sized polymers and biocomposites materials in plant science are being developed (Khot et al., 2012). Nanomaterials are materials with a particle size between 1 and $100 \mathrm{~nm}$ and implicate new physical, chemical and biological properties compared to bulk size materials (Monica \& Cremonini, 2009). Also, some researchers think that absorption of nanoparticles in plants is greater than the same chemicals applied to the plant in bulk size (Braunack, 1995; Suriyaprabha et al., 2012). Although some recent studies on the effects of $\mathrm{SiO}_{2}$ nanoparticles (hereafter SNPs) on plant growth have been performed, these studies are still scarce. For instance, Bao-shan et al. (2004) immersed the roots of Changbai larch (Larix olgensis) seedlings in 62 to $2000 \mu 1 \mathrm{~L}^{-1}$ concentrations of nanosilica for 6 hours and showed positive effects of silicon nanoparticles on seedling's growth. In addition, Haghighi et al. (2012) applied nano-silicon to tomato seeds and seedlings subjected to salt stress and concluded that nano-silicon application reduced the deleterious effects of salinity on germination; root length and plant dry weight. Also, Haghighi \& Pessarakli (2013) showed that application of silicon in nano and bulk size was beneficial in improving the salt tolerance of tomato plants. SNPs improved seed germination and seedling growth of lentil (Lens culinaris Medik) under salinity stress (Sabaghnia \& Janmohammadi, 2015). Zarafshar et al. (2015) reported no toxic effects of SNPs on pear seedlings even when the seedlings were irrigated with high concentrations of SNPs. Nevertheless, the silicon nanoparticles role on plant physiological behaviour is poorly understood (Lee et al., 2010; da Silva Lobato et al., 2013). In fact, $\mathrm{Si}$ is the second most abundant element in soil, however, is not considered as an essential plant mineral nutrient; but its beneficial effects on growth of many plants, especially growing under biotic and abiotic stress conditions have been demonstrated (Chalmardi et al., 2014; Ma \& Yamaji, 2006, 2015). In previous research, investigators have shown that silicon enhances plants resistance to drought, salinity, cold, heat, and metal toxicity. For example, Ashkavand et al. (2015) found that SNPs play a positive role in maintaining critical physiological and biochemical functions in Hawthorn seedlings subjected to drought stress. Thus, it seems that the application of silicon nanoparticles looks promising (and non-expensive) agronomic practice to reduce detrimental environmental effects due to drought (Xie et al., 2015; Balakhnina \& Borkowska, 2013).

The present study aimed to test the effects of SNPs pre-treatments on subsequent drought stress responses of Prunus mahaleb seedlings, a woody species widely distributed in western and central Asia, and Mediterranean countries (Özçelik et al., 2012). Our working hypothesis is that SNPs pretreatment alleviates the detrimental effects of a subsequent drought due to a reduced impact on root growth and elongation (concerning nonSNPs pre-treated seedlings). We expect that under severe drought SNPs pretreated seedlings have a better physiological performance regarding higher photosynthesis and stomatal conductance, lower accumulation of proline, reduced lipid peroxidation and lower chlorophyll degradation concerning that of seedlings non-pretreated with SNPs.

\section{Materials and Methods}

\section{Experimental materials}

In late winter 108 dormant (uniformly-sized) one-year-old Mahaleb seedlings (Prunus mahaleb L. or syn. Cerasus mahaleb L. Mill. Rosaceae) were obtained from an Iranian forest nursery, and transferred to the experimental garden facility at the Faculty of Natural Resources and Marine Sciences of Tarbiat Modares University, Noor, Mazandaran, IRAN (Latitude $35^{\circ} 43^{\prime} 46^{\prime \prime} \mathrm{N}$, longitude $51^{\circ} 23^{\prime}$ 15 " E). The seedlings were transplanted to plastic pots $(7 \mathrm{~L})$ containing a mixture of forest brown soil, 
river sand, and clay $(2: 1: 1 \mathrm{v} / \mathrm{v} / \mathrm{v})$ and grown in a greenhouse with day/night average temperatures of $30 / 21^{\circ} \mathrm{C}$. The soil contained $28 \%, 46 \%$ and $26 \%$ of silt, sand and clay (respectively), $0.87 \%$ of organic carbon, and $30 \mathrm{ppm}$ of available phosphorus.

Examined material. IRAN, Mazandaran, Noor, 14-II-2015, P. Ashkavand 81-85 (HKS, Research Center of Agricultural and Natural Resources Kurdistan Province).

Nanoparticles pre-treatments and imposition of drought stress

After potting, SNPs (acquired from Tecnología Navarra de Nanoproductos S.L., Spain) were applied at four concentrations $\left(0,10,50\right.$ and $\left.100 \mathrm{mg} \mathrm{L}^{-1}\right)$ for $45 \mathrm{~d}$. The SNPs were white coloured, within a size range of 10 to $15 \mathrm{~nm}$, and specific surface area ranging from 180 to $270 \mathrm{~m}^{2} \mathrm{~g}^{-1}$. The seedlings were irrigated to field capacity $\left(300 \mathrm{~mL} \mathrm{pot}^{-1}\right)$ with SNPs suspensions every three days. There were 27 seedlings in each SNPs treatment. At the end of the SNPs treatments (day 45), seedlings in each SNPs treatment were randomly allocated to one of three soil moisture stress groups $(n=9)$. Seedlings were then subjected to three watering treatments consisting on irrigation with tap water every three $\mathrm{d}$ with (i) $300 \mathrm{~mL} \mathrm{pot}^{-1}$ (i.e. control/ low stress), (ii) $150 \mathrm{~mL} \mathrm{pot}^{-1}$ (i.e. moderate stress) and (iii) no irrigation (i.e. severe stress). The criterion used to finish the experiment was the beginning of leaf rolling in seedlings subjected to severe drought, which occurred after $19 \mathrm{~d}$ of treatments.

\section{Plant physiological parameters measurements}

Net photosynthesis (A, $\mu \mathrm{mol} \mathrm{m} \mathrm{m}^{-2} \mathrm{~s}^{-1}$ ), stomatal conductance $\left(\mathrm{g}_{\mathrm{s}}, \mathrm{mmol} \mathrm{m} \mathrm{m}^{-2} \mathrm{~s}^{-1}\right)$ and transpiration rate (E, mmol m $\mathrm{m}^{-2} \mathrm{~s}^{-1}$ ) were measured at 7, 14 and $19 \mathrm{~d}$ after the watering treatments began. They were made on 2-3 leaves from the upper third of each plant of six randomly selected individuals. Measurements were done on sunny days (between 09:00 and 11:00h) at temperatures ranging from 22 to $28{ }^{\circ} \mathrm{C}$, using a portable infrared gas analyser (Model LCpro+, ADC BioScientific Ltd., Hertfordshire, UK). Average values of leaf temperature and internal $\mathrm{CO}_{2}$ concentrations were $27.5 \pm 3.1^{\circ} \mathrm{C}$ and $340 \pm 11.9 \mathrm{ppm}$, respectively.

Predawn xylem stem water potential ( $\psi$ stem, $\mathrm{MPa}$ ) was measured with a pressure chamber system supplied with compressed nitrogen (Skye, SKPM 1400, UK) on day 19. Complementarily, relative water content (RWC) of leaves was determined at midday (from 13 to $15 \mathrm{pm}$ where maximum evaporative demand potentially occur) according to the following description: four leaves (located in the upper third of plants) were removed from randomly selected plants in each treatment, immediately weighed (Wi), and placed in tubes with deionized water for $24 \mathrm{~h}$ at room temperature under low light. After that, individual leaves were reweighed to determine their turgid weights (Wf). Finally, the samples were placed in an oven at $60{ }^{\circ} \mathrm{C}$ for $48 \mathrm{~h}$ and then reweighed to obtain their dry weights (Wd). RWC was calculated by the following equation:

$$
\mathrm{RWC}=\left[\left(\mathrm{W}_{\mathrm{i}}-\mathrm{W}_{\mathrm{d}}\right) /\left(\mathrm{W}_{\mathrm{f}}-\mathrm{W}_{\mathrm{d}}\right)\right] * 100
$$

\section{Plant morphological parameters and growth}

At the end of the experiment (i.e. day 19 after a drought), the primary stem length, collar diameter, longest root, and root volume of all seedlings were measured. Root length was measured using a scaled ruler, and root volumes were measured through water displacement in graduated cylinders. Afterwards, seedlings were harvested separating roots and shoots (i.e. aerial organs), and then all tissues were oven dried for $48 \mathrm{~h}$ at $70{ }^{\circ} \mathrm{C}$ to obtain their corresponding dry weights.

Determination of thiobarbituric acid-reactivesubstances (TBARs) and membrane electrolyte leakage (ELI)

Thiobarbituric acid reaction (TBA) was measured as described by Heath \& Packer (1968). Leaf fresh mass $(200 \mathrm{mg})$ was homogenised in $2 \mathrm{ml}$ of $0.1 \%(\mathrm{w} / \mathrm{v})$ trichloroacetic acid (TCA), followed by centrifugation at $12.000 \times g$ for 20 min. The supernatant $(1 \mathrm{~mL})$ was mixed with an equal volume of TCA $(10 \%)$ containing $0.5 \%(\mathrm{w} / \mathrm{v})$ TBA or no TBA as the blank and heated at $95^{\circ} \mathrm{C}$ for $30 \mathrm{~min}$ and then cooled in ice. The reaction product was centrifuged at $12.000 \times g$ for $15 \mathrm{~min}$, and the supernatant absorbance was measured at 400, 532 and $600 \mathrm{~nm}$.

Leaves were cut into 1-to- $2 \mathrm{~cm}^{2}$ pieces and placed in test tubes with $20 \mathrm{~mL}$ deionised distilled water (0.5-0.8 $\mathrm{g}$ fresh leaf tissue per sample). After vortexing, the samples for $3 \mathrm{~s}$, the initial electrical conductivity $\left(\mathrm{EC}_{0}\right)$ of each sample was measured. The samples were stored at $4^{\circ} \mathrm{C}$ for $24 \mathrm{~h}$, and conductivity $\left(\mathrm{EC}_{1}\right)$ was measured again. Samples 
were then autoclaved for $15 \mathrm{~min}$, cooled to room temperature, and conductivity $\left(\mathrm{EC}_{2}\right)$ was measured for the third time. The electrolyte leakage index (ELI) of cell membranes was calculated using a modification of the method of Zhao et al. (1992) as:

$$
\operatorname{ELI}(\%)=\left[\left(\mathrm{EC}_{1}-\mathrm{EC}_{0}\right) /\left(\mathrm{EC}_{2}-\mathrm{EC}_{0}\right)\right] * 100
$$

\section{Measurements of biochemical parameters}

At the end of the experiment, fresh leaf samples were covered with aluminium foil, frozen in liquid nitrogen and stored at $-85^{\circ} \mathrm{C}$ until used for biochemical analysis. Chlorophylls and carotenoids were extracted from leaf samples in $80 \% \mathrm{v} / \mathrm{v}$ acetone, and their contents were determined by spectrophotometry according to Gholami et al. (2012). Free proline content in leaves was quantified following the procedure of Bates et al. (1973) as cited by Nikolaev et al. (2010).

\section{Microscopic observations}

At the end of the experiment, the fresh root sections were taken for microscopic analysis. The adsorption of SNPs to fresh roots was observed by scanning electron microscopy (SEM) (KYKYEM3200) in the laboratory of Tarbiat Modares University.

\section{Measurements of leaf nutrient elements}

Oven-dried leaves were pulverised in an electric mill. The powdered leaf tissues were transmitted to the atomic energy organisation of Iran (AEOI). The concentrations of $\mathrm{Si}, \mathrm{N}, \mathrm{P}$, and $\mathrm{K}$ were detected by X-ray fluorescence analysis (XRF; ED 2000 Oxford Instruments Corporation) following the methodological considerations by Towet et al. (2016).

\section{Statistical analysis}

Physiological data were analysed through repeated measures ANOVA (rmANOVA). All other variables were assessed using two-way ANOVAs in a fixed factor model. For comparison between groups, Duncan's multiple range tests were applied at 0.05 probability level. In case of percentage data, arcsine transformation was applied before ANOVA analyses. All data were tested for normality, homogeneity of variance and Mauchly's test before ANOVA. Statistical analyses were performed using SPSS software (IBM SPSS Statistics).

\section{REsULTS}

Confirmation of the presence of SNPs in treated roots

Elements consistent in size with the SNPs were adsorbed by the roots in the treated seedlings but not in the untreated ones (Data not shown). Observation of the root system of treated plants revealed the presence of nanoparticles attached to the roots at the highest SNPs concentration $\left(100 \mathrm{mg} \mathrm{L}^{-1}\right)$ while few nanoparticles were observed in roots treated with SNPs of 10 and $50 \mathrm{mg} \mathrm{L}^{-1}$.

\section{Effect of SNPs pre-treatments on leaf physiological} parameters

There were no differences in leaf physiological parameters between SNP-treated and untreated seedlings before drought stress. The photosynthesis rate (A), stomatal conductance (gs) and transpiration (E) were affected by SNPs treatments after drought stress (repeated measures ANOVA; treatment and treatment $\mathrm{x}$ time effect: $\mathrm{P}<0.001)$. The positive effect of SNPs pre-treatments on A and gs was evident after 19 days of no irrigation (severe water stress; Fig. 1 right panels), where seedlings pretreated with 50 , and $100 \mathrm{mg} \mathrm{L}^{-1} \mathrm{SNPs}$ registered significantly higher values for such parameters than those of control plants (i.e. with no addition of SNPs). Under moderate water stress $(150 \mathrm{~mL}$ every $3 \mathrm{~d})$, the beneficial effects of SNPs application were less notorious for all variables than under severe drought. Under well-watered conditions ( $300 \mathrm{~mL}$ every $3 \mathrm{~d}$ ), application of SNPs did not provoke any significant effect on the physiological parameters measured (Fig. 1 left panels). Responses in E paralleled those of gs in most of the cases under either water treatment condition.

Root morphology and biomass responses to drought as affected by SNPs pre-treatments

Under severe water stress (no irrigation for 19d), seedlings pretreated with any concentration of SNPs had longer roots than those of non treated with SNPs (Fig. 2A). Under moderate stress conditions (150 $\mathrm{mL}$ every $3 \mathrm{~d}$ ) the pattern was less obvious although longer roots were recorded on seedlings pretreated with $50 \mathrm{mg} \mathrm{L}^{-1}$ SNPs with respect to all other concentrations. Interestingly, the use of SNPs on well-watered conditions ( $300 \mathrm{~mL}$ every $3 \mathrm{~d}$ ) was also positive on the length of roots, where longer roots were attained at increasing concentration of SNPs 

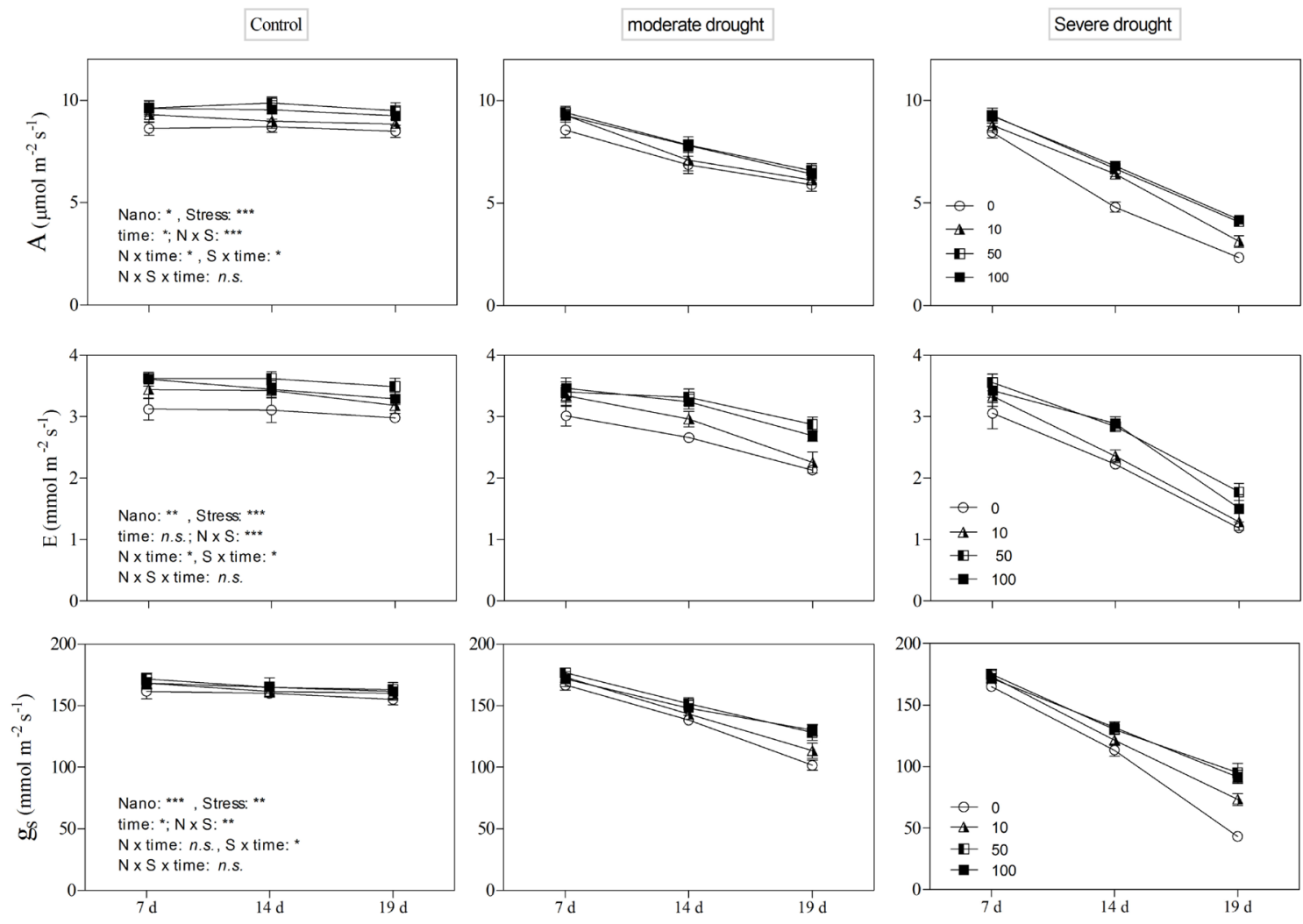

Fig. 1. Responses of photosynthesis rate $(A)$, stomatal conductance $\left(g_{s}\right)$ and leaf transpiration rate $(E)$ of Prunus mahaleb seedlings pretreated with different concentration of SNPs during 45 days, and subsequently subjected to 19 days to three irrigation treatments $(0,150$ and $300 \mathrm{~mL}$ of water every 3 days [severe drought, moderate drought and well-watered controls, respectively]). Gas exchange measurements were done using a portable infrared gas analyser (Model LCpro+, ADC BioScientific Ltd., Hertfordshire, UK) on fully expanded leaves located in the upper third of the plant of six randomly selected individuals at days 7, 14 and 19 after drought. (Mean $\pm S E ; n=6$ ). *: $P<0.05 ;{ }^{* *} P<0.01$; ${ }^{* * *}$ : $P<0.001$; n.s.: $P>0.05$.

applied (Fig. 2A). Root volume of plants subjected to moderate drought was less enhanced by SNPs application than root length, suggesting that these roots also had a lower diameter (Fig. 2B). In contrast, seedlings growing under both moderated stress and well-watered conditions displayed an increase in root volume than root length when SNPs were applied at 50 and $100 \mathrm{mg} \mathrm{L}^{-1}$ (Fig. 2B), which suggest an increase in root diameter. In general, positive effects of SNPs on the whole plant dry weights under three irrigation regimes were observed. Root biomass was slightly higher in plants pretreated with SNPs, but shoot biomass was not (Fig. 2C). These responses viewed in dry mass terms were in line with the better physiological performance and the increase in root lengthening due to the use of SNPs previous to the drought treatment application.

Water relations and biochemical parameters responses to drought in seedlings pretreated with SNPS

Relative leaf water content (RWC) decreased with increasing severity of the drought, but it was not affected by SNPs pre-treatments (Fig. 3A). Xylem water potential (XWP) was affected by drought depending on $\mathrm{SiO}_{2} \mathrm{NPs}$ pre-treatment. On this note, higher XWP was detected in seedlings subjected to severe drought at increasing application of SNPs, thereby a better water status was seen particularly in those seedlings pretreated with $100 \mathrm{mg} \mathrm{L}^{-1}$ of 

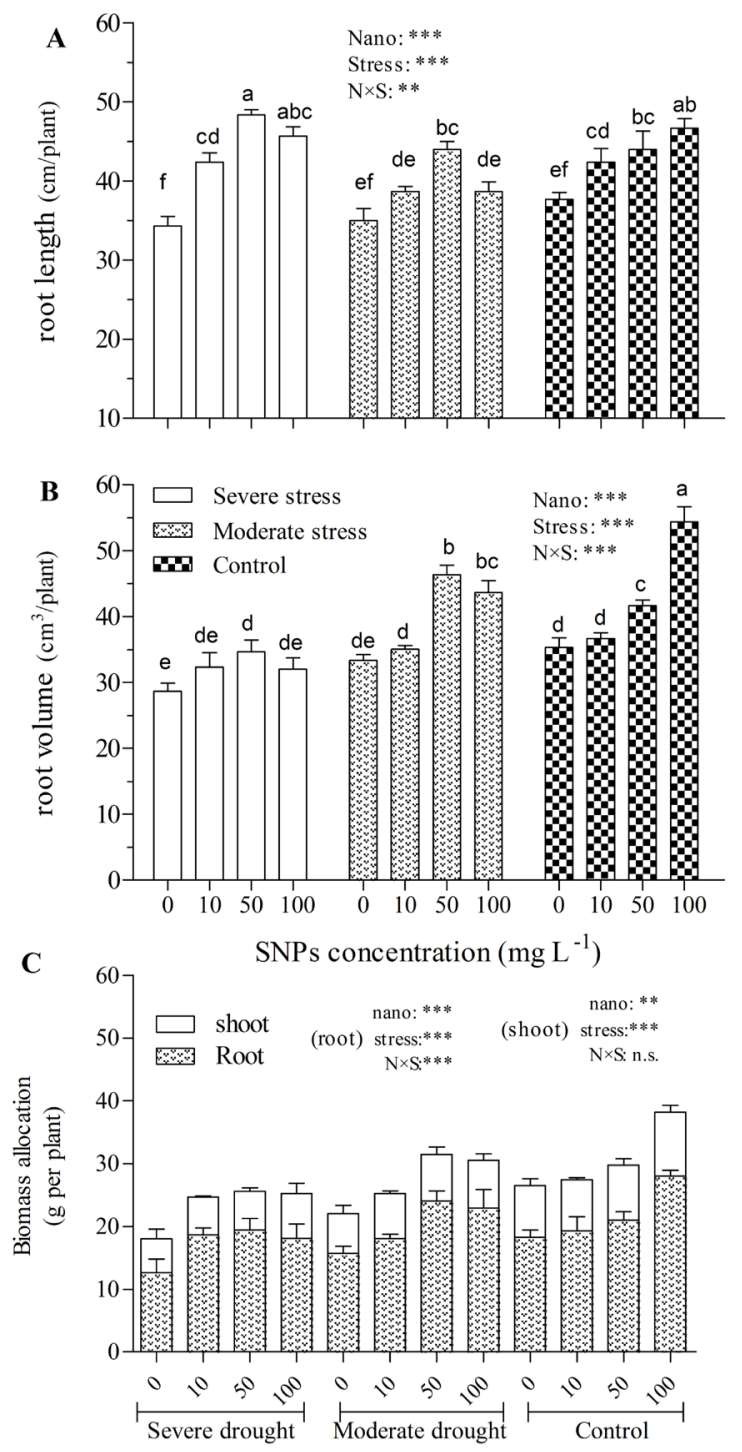

Fig. 2. A: Root length, B: root volume, C: and biomass allocation of Prunus mahaleb seedlings pre-treated with different concentration of SNPs during 45 days, and subsequently subjected to 19 days to three irrigation treatments $(0,150$ and 300 $\mathrm{mL}$ of water every 3 days [severe drought, moderate drought and well-watered controls, respectively]).

SNPs in the severe drought regime (Fig. 3B). Under moderate stress conditions, the beneficial effect of nanoparticles on XWP was true for those seedling pretreated with 50 and $100 \mathrm{mg} \mathrm{L}^{-1}$ of SNPs under severe or moderate drought. Under well-watered conditions, XWP - naturally higher on average than under water stress - was similar irrespective of SNPs pretreatment (Fig. 3B). The electrolyte leakage index (ELI) values registered in tissues of seedlings subjected to severe drought were more than 2-fold higher than those of seedlings exposed to moderate stress or irrigated conditions, which did not differ for this parameter (Fig. 3C). Application of SNPs did not change ELI under either irrigation treatment. TBARs in leaf tissues, as an indicator of lipid peroxidation, was affected by SNPs depending on the irrigation regime (see the significant interaction between factors in Fig. 3D). The highest values for TBARs were registered under severe drought in non-SNPs pretreated plants. Also, SNPs application at higher concentration (100 $\left.\mathrm{mg} \mathrm{L}^{-1}\right)$ under severe drought determined a significant reduction in TBARs comparable to the values obtained under moderate drought (Fig. 3D). These results are in line with the slightly better water status of plants pretreated with SNPs at higher concentration under stressful drought conditions. It should be noticed that TBARs values allowed to distinguish the protection by SNPs when under severe drought conditions while ELI did not (compare Fig. 3C and Fig. 3D).

Total chlorophyll concentration in non-SNPs pretreated seedlings decreased by $33 \%$ under severe drought (Table 1). SNPs pretreatment (50 and 100 $\mathrm{mg} \mathrm{L}^{-1}$ ) enhanced chlorophyll concentration in seedlings subjected to severe drought. Moderate drought conditions did not affect this parameter when SNPs under either concentration was previously applied (Table 1). Under severe drought, carotenoids were progressively higher at increasing SNPs concentrations as pretreatments $(1.40 \mathrm{vs} 2.77 \mathrm{mg} / \mathrm{g}$ in seedlings non-SNPs-treated and treated with $100 \mathrm{mg}$ $\mathrm{L}^{-1}$ of SNPs), even clearer than when under moderate drought conditions (Table 1). The concentration of free proline was highest under severe stress in seedling that did not receive SNPs application. Interestingly, SNPs used as a pretreatment at 50 and $100 \mathrm{mg} \mathrm{L}^{-1}$ determined a $24-27 \%$ reduction in proline concentration in leaves (Table 1). Under moderate drought, the values for this parameter were similar than those obtained from control seedlings.

Effect of SNPs pre-treatments on leaf concentrations of N, P, K and Si after drought

To verify the effect of SNPs pretreatments on the nutrient uptake in Mahaleb seedlings, we studied the concentrations of three main mineral elements such 

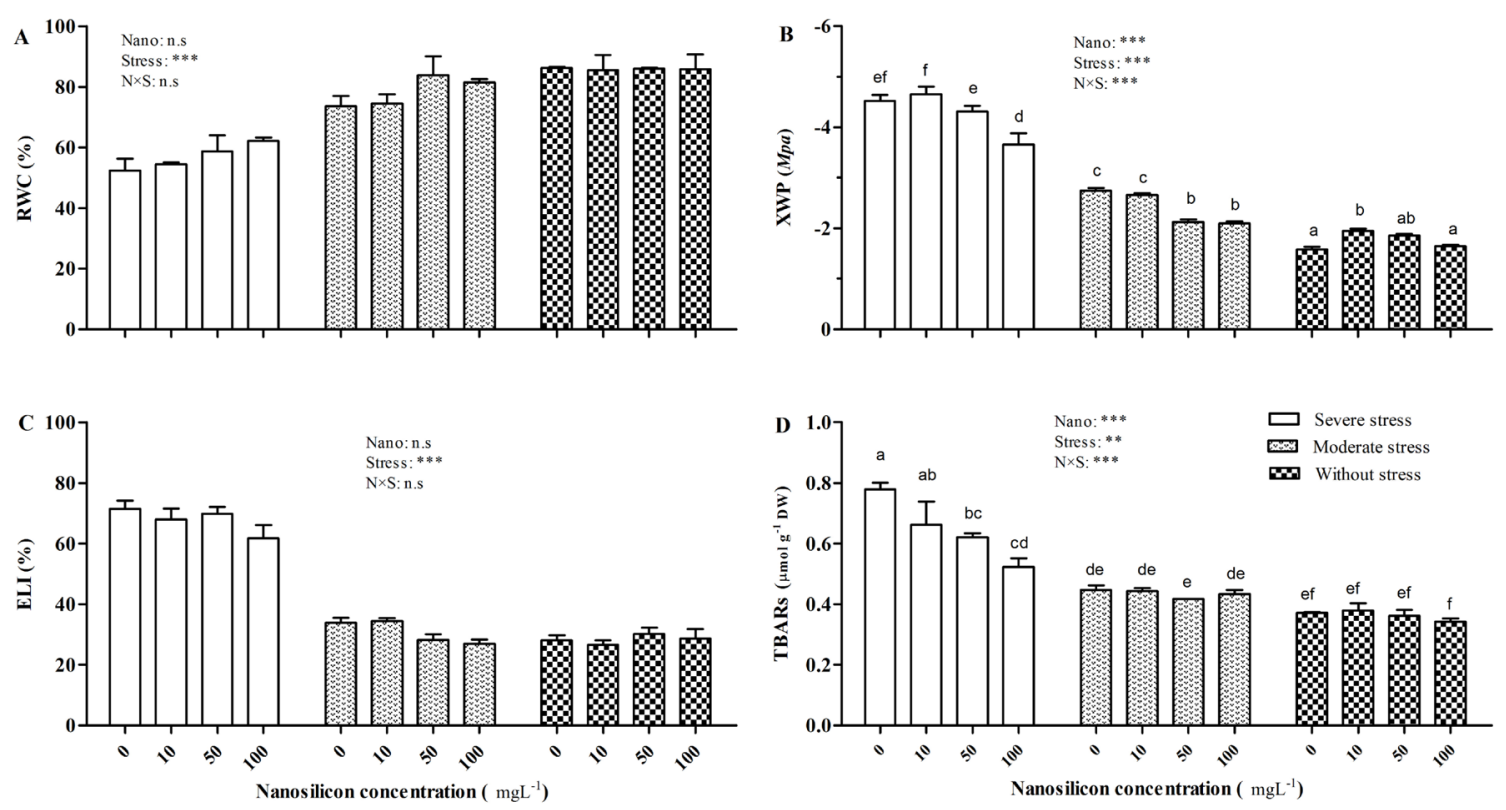

Fig. 3. Water relations parameters (A: relative water content, B: xylem water potential, C: electrolyte leakage index-ELI and D: thiobarbituric acid-reactive-substances (TBARs) of Prunus mahaleb seedlings pretreated with different concentration of SNPs during 45 days, and subsequently subjected to 19 days to three irrigation treatments $(0,150$ and $300 \mathrm{~mL}$ of water every 3 days [severe drought, moderate drought and wellwatered controls, respectively]). Different letters indicate significant differences $(P<0.05)$ among treatments based on the Duncan tests. (Mean $\pm S E ; n=6$ ). ${ }^{*}: P<0.05$; ${ }^{* *} P<0.01$; ${ }^{* * *}: P<0.001$; n.s.: $P>0.05$.

as $\mathrm{N}, \mathrm{P}$ and $\mathrm{K}$, and also $\mathrm{Si}$ in seedlings subjected to severe drought (no irrigation during $19 \mathrm{~d}$ ) and wellwatered control by applying X-ray fluorescence. The concentration of $\mathrm{N}$ in leaves under severe drought was higher in seedlings pretreated with 50 and $100 \mathrm{mg} \mathrm{L}^{-1}$ SNPs compared to those non-treated with SPNs (Fig. 4B). Furthermore, improvement in leaf $\mathrm{N}$ concentration by SNPs when in severe drought determined that such parameter reached similar values than those of well-watered control seedlings (Fig. 4B). The concentration of $\mathrm{P}$ in leaf tissues in seedlings exposed to drought was enhanced by pretreatment with high doses of SNPs (i.e. 50 and $100 \mathrm{mg} \mathrm{L}^{-1}$ ) compared to those non-pretreated with SNPs (Fig. 4C). Interestingly, seedlings growing under well-watered conditions had higher leaf $\mathrm{P}$ concentrations when pretreated with either SNPs concentration with respect to those that did not receive SNPs application as a pretreatment (Fig. 4C). In the case of K, SNPs application did not affect the concentration of $\mathrm{K}$ in leaves, except $100 \mathrm{mg} \mathrm{L}^{-1}$ SNPs pretreatment of well-watered seedlings, which attained a slightly higher $\mathrm{K}$ concentration with respect to all other treatment combinations (Fig. 4D). Finally, Si concentration in leaf tissues was significantly higher at increasing SNPs concentrations when seedlings grew under control conditions (Fig. 4A) whereas in seedlings subjected to drought a similar increase in leaf $\mathrm{Si}$ concentration was observed at either SNPs pretreatment (10, 50 and $\left.100 \mathrm{mg} \mathrm{L}^{-1}\right)$, which was higher than of seedlings non-pretreated with SNPs (Fig. 4A).

\section{Discussion}

The application of Si nanoparticles (SNPs) can improve the growth of several crops and increase their tolerance to biotic and abiotic stresses (Richmond \& Sussman, 2003; Ma, 2004; Ahmed et al., 2014) but data on woody plants (and particularly in tree fruit species) were scarce. In our research, we have applied different concentrations 
Bol. Soc. Argent. Bot. 53 (2) 2018

Table 1. Total chlorophyll, carotenoids and free proline concentrations (dry weight basis) of Prunus mahaleb seedlings pretreated with different concentration of SNPs during 45 days, and subsequently subjected to 19 days to three irrigation treatments $(0,150$ and $300 \mathrm{~mL}$ of water every 3 days [severe drought, moderate drought, and well-watered controls, respectively]).Different letters indicate significant differences $(P<0.05)$ among treatments based on the Duncan tests. (Mean $\pm S E ; n=6)$.

\begin{tabular}{|c|c|c|c|}
\hline Treatment & Control & Moderate Drought & Severe Drought \\
\hline \multicolumn{4}{|c|}{ Chlorophyll a+b ( $\mu \mathrm{g} / \mathrm{g})$} \\
\hline $0 \mathrm{mgL}-1$ & $9.38 \pm 0.34 \mathrm{~cd}$ & $7.53 \pm 0.52 \mathrm{de}$ & $6.26 \pm 0.47 \mathrm{e}$ \\
\hline $10 \mathrm{mgL}-1$ & $10.79 \pm 0.16 b c$ & $10.29 \pm 0.45 a b$ & $7.19 \pm 0.57 \mathrm{de}$ \\
\hline 50 mgL-1 & $10.39 \pm 0.32 b c$ & $9.99 \pm 0.3 b c$ & $9.09 \pm 0.52 b c$ \\
\hline 100 mgL-1 & $11.11 \pm 0.09 a b$ & $12.04 \pm 0.35 a$ & $9.76 \pm 0.53 a b$ \\
\hline \multicolumn{4}{|c|}{ Carotenoid (mg/g) } \\
\hline $0 \mathrm{mgL}-1$ & $2.21 \pm 0.07 \mathrm{ce}$ & $1.60 \pm 0.09 \mathrm{~g}$ & $1.40 \pm 0.06 \mathrm{~g}$ \\
\hline $10 \mathrm{mgL}-1$ & $2.63 \pm 0.3 b$ & $1.93 \pm 0.06$ ef & $1.48 \pm 0.09 \mathrm{fg}$ \\
\hline $50 \mathrm{mgL}-1$ & $2.39 \pm 0.07 \mathrm{bd}$ & $2.08 \pm 0.07 \mathrm{e}$ & $2.10 \pm 0.15 b c$ \\
\hline 100 mgL-1 & $2.41 \pm 0.08 \mathrm{bd}$ & $1.74 \pm 0.08 \mathrm{fg}$ & $2.77 \pm 0.08 a$ \\
\hline \multicolumn{4}{|c|}{ Free proline $(\mu \mathrm{g} / \mathrm{g})$} \\
\hline $0 \mathrm{mgL}-1$ & $105.83 \pm 1.89$ ef & $108.12 \pm 0.68 \mathrm{~cd}$ & $141.45 \pm 1.55 a$ \\
\hline $10 \mathrm{mgL}-1$ & $102.60 \pm 2.65 \mathrm{fg}$ & $105.50 \pm 0.57 \mathrm{de}$ & $132.87 \pm 0.43 b$ \\
\hline $50 \mathrm{mgL}-1$ & $109.61 \pm 2.10 \mathrm{de}$ & $110.61 \pm 0.07 \mathrm{de}$ & $102.81 \pm 0.23 c$ \\
\hline 100 mgL-1 & $99.96 \pm 4.72 \mathrm{~g}$ & $96.01 \pm 1.74 \mathrm{~g}$ & $106.57 \pm 1.53 c$ \\
\hline
\end{tabular}
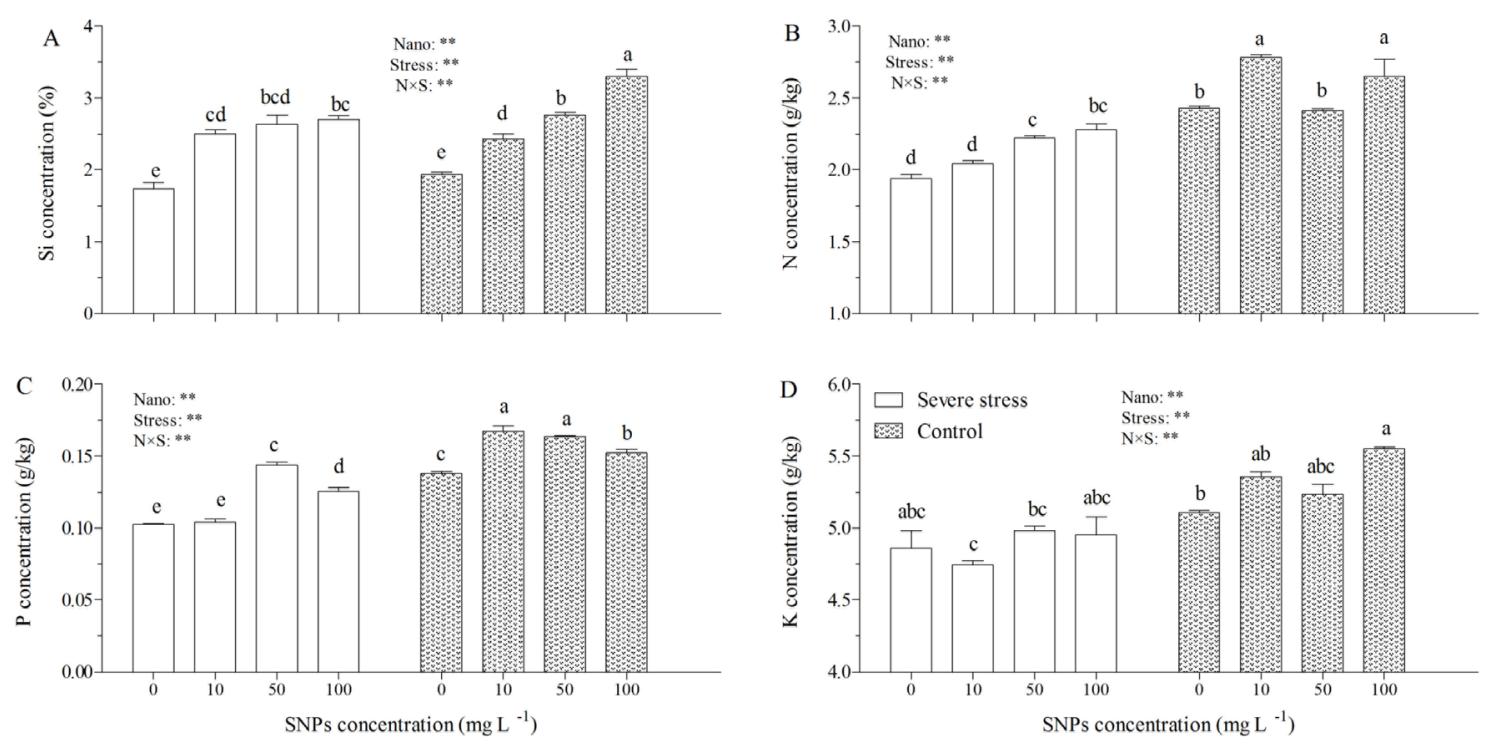

Fig. 4. Concentration of $\mathrm{Si}, \mathrm{N}, \mathrm{P}$ and $\mathrm{K}$ in leaf tissues of Prunus mahaleb seedlings (dry weight basis) pretreated with different concentration of SNPs during 45 days, and subsequently subjected to 19 days of three irrigation treatments $(0,150$ and $300 \mathrm{~mL}$ of water every 3 days [severe drought, moderate drought and well-watered controls, respectively]). Different letters indicate significant differences $(p<0.05)$ among treatments based on the Duncan tests. (Mean $\pm \mathrm{SE} ; \mathrm{n}=6$ ). ${ }^{*}: \mathrm{P}<0.05 ;{ }^{* *} \mathrm{P}<0.01$; ${ }^{* * *}: \mathrm{P}<0.001 ;$ n.s.: $\mathrm{P}>0.05$. 
of SNPs for 45 days to Prunus mahaleb (Mahaleb) seedlings, and afterwards, they were subjected to drought to assess the role of SNP pre-treatment on plant physiological responses of this woody species. Based on our results, SNP application at concentrations of 50 and $100 \mathrm{mg} \mathrm{L}^{-1}$ was clearly beneficial to Mahaleb seedlings given the improvement of its drought tolerance. Positive effects of Si were reported in many plant species such as wheat, rice, cucumber, maize and bamboo, in particular, under stressful conditions (Ma \& Takahashi, 2002; Shi et al., 2005; Zhang et al., 2008; Vaculik et al., 2009; Feng et al., 2010; Collin et al., 2014; $\mathrm{Xu}$ et al., 2015). In the case of $P$. mahaleb, we found that the positive effects of SNPs were evident when seedlings were later exposed to drought stress. Seedlings pretreated with SNPs showed less impact of severe drought (no irrigation) on root length - as an indicator of potential for water and nutrient uptake - and displayed a better physiological behaviour regarding photosynthesis, stomatal conductance, and xylem water potential when compared to seedlings non-pretreated with SNPs. Such better physiological performance of SNPs pretreated seedlings was related to the maintenance of leaf nutritional status, which showed comparable concentrations of $\mathrm{N}$ and $\mathrm{P}$ than those of never-stressed (control) seedlings. Along the experiment, the improved tolerance by SNPs to drought was reflected in higher biomass accumulation, particularly of roots. Therefore, we can accept our hypothesis by which we proposed that SNPs pre-treatments alleviate the detrimental effects of a subsequent severe drought. Also, it is interesting to notice that there were no apparent associated biological costs of SNPs application regarding growth when plants grew under control conditions as well watered seedlings pretreated with the highest SNPs concentration $\left(100 \mathrm{mg} \mathrm{L}^{-1}\right)$ attained the highest dry mass. The mechanisms underlying this growth promotion even when seedlings were well irrigated deserves further experimental investigation.

Cell expansion and, consequently, shoot and root elongation are sensitive responses to drought stress (Lambers et al., 2008). Important responses to SNPs pretreatment on seedlings exposed to severe drought were the maintenance of the root length and the amelioration of the negative impact of water deficit on root volume and root biomass accumulation with respect to non-pretreated seedlings. These results are in line with the better physiological water status of seedlings in terms of xylem water potential (XWP) due to the presence of SNPs (100 $\left.\mathrm{mg} \mathrm{L}^{-1}\right)$ as shown also in adult plants of this species when subjected to summer drought given its deep roots compared to other coexistent woody species like Quercus pubescens and Ostrya carpinifolia (see Figure 2 in Nardini et al., 2015). This better water status indicated by XWP was not reflected in improved leaf relative water content (RWC) as could be expected (see also Zarafshar et al., 2014). So, SNPs aided plants to maintain root length and decreased the impact on XWP but not on RWR. In this respect, Zhang et al. (2013) found that silicon application did not enhance leaf RWC of Chestnut plants subjected to water deficit as well as it was found by Ashkavand et al. (2015) on hawthorn seedlings. Curiously, it seems that SNPs application did not aid to improve leaf RWC in woody plants (eg. Zhang et al., 2013; Ashkavand et al., 2015) but it does it in herbaceous crop species such as sorghum (Kafi et al., 2011), cotton, canola, and wheat (Mehrabanjoubani et al., 2015). Gadallah (2000) proposed that RWC improvement could be due to (i) an enhanced water uptake resulting from a more developed root system and (ii) a reduction of water loss by transpiration. In our experiment, RWC was not improved by SNPs application as leaf transpiration was not reduced as stomatal conductance remained higher despite Mahaleb seedlings growing under severe drought developed longer roots, which increased the potential for water uptake and, explained - at least partially - the amelioration of drought impact on XWP.

Leaf gas exchange was negatively affected by drought intensity along time but to a lesser extent when seedlings were pretreated with SNPs at high concentrations (50 and $100 \mathrm{ml} \mathrm{L}^{-1}$ SNPs; Fig. 1). In agreement with findings by Matoh et al. (1986) for rice, we found that under severe drought conditions, stomatal conductance was 2-fold higher in seedlings that received SNPs application than those that did not. In this sense, besides the relation between the water status, cell turgor, and stomatal aperture, Agarie et al. (1998) reported positive effects of silicon $(\mathrm{Si})$ on stomatal conductance in rice, which likely play a role in the responses of stomata cells to blue light (Agarie et al., 1999). Nevertheless, the 
specific mechanism by which Si regulates stomatal responses in woody species remains unclear in and needs further experimental investigation (Gao et al., 2005). The magnitude of the retained stomatal conductance of SNPs pre-treated seedlings were the same than the retained capacity for carbon fixation of such seedlings (Figure 2) as it was previously informed for maize (Kaya et al., 2006), cherry tomatoes (Haghighi \& Pessarakli, 2013), chestnut (Zhang et al., 2013) and Hawthorn (Ashkavand et al., 2015). Moreover, such less impacted photosynthesis matched with the maintenance of chlorophyll and carotenoids levels when compared to that of controls seedlings (Table 1). Therefore, seedlings pretreated with SNPs displayed a less negative impact on drought on stomatal aperture, carbon fixation, and photosynthetic pigments showing the beneficial effects of SNPs pre-treatments on physiological performance when facing a subsequent drought period.

Alleviation of drought stress by SNP application was also clear in biochemical parameters as free proline, and TBARs had lower concentrations when seedlings were pretreated with SNPs than when they were not (Table 1 and Figure 3D, respectively). In general, we found that free proline in leaves at all watering regimes decreased at increasing of SNPs concentration similarly to what has been documented in soybean plants under salinity stress (Lee et al., 2010) and drought stress (Shen et al., 2010). The accumulation of free proline under stressful conditions (no irrigation plus non-SNPs pretreatment) might be regarded as indicative of the osmotic adjustment capability of this species. Also, seedlings that received an application of SNPs previous to water withholding were less stressed than those without SNPs pretreatment as indicated the leaf gas exchange responses already discussed. On the other hand, TBARs, an indicator of oxidative damage to membrane lipids under stress (Ozkur et al., 2009), was the highest under severe drought conditions in seedlings non-pretreated with SPNs while those pretreated with silicon nanoparticles registered progressively lower concentrations of TBARs at increasing SNPs application. Again, this finding illustrates that exogenous SNPs application relieves drought-induced injury in Mahaleb seedlings. Such relief would be associated with the maintenance of root length and its functionality (Fig. 3A; see also Zarafshar et al., 2015).
The application of SNPs not only alleviated the effects of drought on plant physiological activity but also enable them to continue with nutrient uptaking of $\mathrm{N}$ and $\mathrm{P}$ and to a lesser extent $\mathrm{K}$, which was reflected in a similar leaf concentration of these nutrients with respect to that of nonstressed seedlings (Fig. 4). The maintenance of the concentration of $\mathrm{N}$ and $\mathrm{P}$ in high levels of seedlings pretreated with SNPs under drought conditions might explain the lowered impact on photosynthesis and plant growth (see also reviews by Zlatev \& Lindon, 2012, and by Ashraf \& Harris, 2013). In this sense, the better status of $N$ and $P$ likely to have an important role in sustaining the photosynthetic rate (Lambers et al., 2008). So, the beneficial effects of SNPs application were also evident in the leaf nutritional status of this species.

In conclusion, as discussed above, the application of silica nanoparticles (SNPs in this report) as pretreatments should be considered as a promising agronomic practice to be tested at field scale in sites prone to suffer from water deficit as SNPs appear to be able to alleviate the common physiological deleterious effects of drought on plants as demonstrated here for Mahaleb.

\section{Bibliography}

AGARIE, S., H. UCHIDA, W. QGATA, F. KUBOTA \& P.B. KAUFMAN. 1998. Effects of silicon on transpiration and leaf conductance in rice plants (Oryza Sativa L). Proc. Crop. Sci. Soc. Jpn. 1: 89-95.

AGARIE, S., H. UCHIDA, W. QGATA \& P.B. KAUFMAN. 1999. Effects of silicon on stomatal blue-light response in rice (Oryza sativa L.). Plant. Prod. Sci.2: 232-234.

AHMED, M., F. UL-HASSAN \& M. ASIF. 2014. Amelioration of drought in sorghum (Sorghum bicolor L.) by silicon. Commun. Soil. Sci. Plant. Anal. 45: 470-486.

ASADZADE, N., S.G. MOOSAVI \& M.J. SEGHATOLESLAMI. 2015. Effect of low irrigation and $\mathrm{Zn}$ and $\mathrm{SiO}_{2}$ nano-fertilizers and conventional fertilizers on morphophysiological traits and seed yield of sunflower. Biol. Forum. Int. J. 7:357-364.

ASHKAVAND, P., M. TABARI, M. ZARAFSHAR, I. TOMÁS̆KOVÁ \& D. STRUVE. 2015. Effect of $\mathrm{SiO}_{2}$ nanoparticles on drought resistance in hawthorn seedlings. For. Res. Paper. 76: 350-359. 
ASHRAF, M. \& H.J.C. HARRIS. 2013. Photosynthesis under stressful environments: An overview. Photosynthetica 51: 163-190.

BALAKHNINA, T. \& A. BORKOWSKA. 2013. Effects of silicon on plant resistance to environmental stresses: review. Int. Agrophys. 27: 225-232.

BAO-SHAN, L., L. CHUN-HUI, F. LI-JUN, Q. SHU-CHUN \& Y. MIN. 2004. Effect of TMS (nanostructured silicon dioxide) on growth of Changbai larch seedlings. J. For. Res. (Harbin) 15: 138-140.

BATES, L.S., R.P. WALDRAN \& I.D. TEARE. 1973. Rapid determination of free proline for water stress studies. Plant. Soil 39: 205-208.

BLOKHINA, O., E. VIROLAINEN \& K. V. FAGERSTEDT. 2003. Antioxidants, oxidative damage and oxygen deprivation stress: A review. Ann. Bot. 91: 179-194.

BRAUNACK, M. 1995.Effect of aggregate size and soil water content on emergence of soybean (Glycine max L. Merr.) and maize (Zea mays L.). Soil. Till. Res.33: 149-161.

CAMPOS, P. S., V. QUARTIN, J.C. RAMALHO \& M.A. NUNES. 2003. Electrolyte leakage and lipid degradation account for cold sensitivity in leaves of Coffea sp. plants. Plant. Physiol. Biochem.160: 283-292.

CHALMARDI, Z.K., A. ABDOLZADEH \& H.R. SADEGHIPOUR. 2014. Silicon nutrition potentiates the antioxidant metabolism of rice plants under iron toxicity. Acta. Physiol. Plant. 36: 493-502.

CHEN, H. \& R. YADA. 2011. Nanotechnologies in agriculture: New tools for sustainable development. Trends. Food. Sci. Technol. 22: 585-594.

COLlin, B., E. DOELSCH, C. KELlER, P. CAZEVIEILLE, M. TELLA, P. CHAURAND, F. PANFILI, J.L. HAZEMANN \& J.D. MEUNIER. 2014. Copper distribution and speciation in bamboo exposed to a high $\mathrm{Cu}$ concentration and $\mathrm{Si}$ supplementation. First evidence on the presence of reduced copper bound to sulfur compounds in Poaceae. Env. Pollut. 187: 22-30.

DA SILVA LOBATO, A. K., E.M.S. GUEDES, D.J. MARQUES \& C. F. DE OLIVEIRA NETO 2013. Silicon: a benefic element to improve tolerance in plants exposed to water deficiency. In Responses of Organisms to Water Stress. InTech.

EGERT, M. \& M. TEVINI. 2002. Influence of drought on some physiological parameters symptomatic for oxidative stress in leaves of chives (Allium schoenoprasum). Environ. Exp. Bot. 48: 43-49.

EPSTEIN, E. 1999. Silicon. Ann. Rev. Plant. Physiol. Plant. Mol. Biol. 50: 641-664.
FAROOQ, M., M. HUSSAIN, A. WAHID \& K.H.M. SIDDIQUE. 2012. Drought stress in plants: an overview. In: Aroca R. (ed.), Plant Responses to Drought Stress, pp. 1-33. Springer, Berlin, Heidelberg.

FENG, J., Q. SHI, X. WANG, M. WEI, F. YANG \& H. XU. 2010. Silicon supplementation ameliorated the inhibition of photosynthesis and nitrate metabolism by cadmium (Cd) toxicity in Cucumis sativus L. Sci. Hortic. 123: 521-530.

GADALLAH,M. A. A. 2000.Effects of indole-3-acetic acid and zinc on the growth, osmotic potential and soluble carbon and nitrogen components of soybean plants growing under water deficit. J. Arid. Environ. 44: 451-467.

GAO, X., C. ZOU, L. WANG \& F. ZHANG. 2005. Silicon improves water use efficiency in maize plants. $J$. Plant. Nutr. 27: 1457-1470.

GHOLAMI, M., M. RAHEMI, B. KHOLDEBARIN \& S. RASTEGAR. 2012. Biochemical responses in leaves of four fig cultivars subjected to water stress and recovery. Sci. Hortic. 148: 109-117.

HAGHIGHI, M. \& M. PESSARAKLI. 2013. Influence of silicon and nano-silicon on salinity tolerance of cherry tomatoes (Solanum lycopersicum L.) at early growth stage. Sci. Hortic. 161: 111-117.

HAGHIGHI, M., Z. AFIFIPOUR \& M. MOZAFARIAN. 2012. The effect of N-Si on tomato seed germination under salinity levels. J.B.E.S. 6: 87-90.

HEATH, R. \& P. PACKER. 1968.Photoperoxidation in isolated chloroplasts. I. Kinetics and stoichiometry of fatty acid peroxidation. Arch. Biochem. Biophys. 125: 189-198.

HU, Y. C. \& U. SCHMIDHALTER. 2005. Drought and salinity: a comparison of their effects on mineral nutrition of plants. J. Plant Nutr. Soil Sci. 168: 541-549.

KAFI, M., J. NABATI, A. MASOUMI \& M.Z. MEHRGERDI. 2011. Effect of salinity and silicon application on oxidative damage of sorghum [Sorgumbicolor (L.) monech.]. Pak. J. Bot.43: 24572462.

KARMOLLACHAAB, A., A. BAKHSHANDEH, M.H. GHARINEH, M.R. MORADITELAVAT \& G. FATHI. 2013. Effect of silicon application on physiological characteristics and grain yield of wheat under drought stress condition. I.J.A.P.P. 4: 30-37.

KAYA, C., L. TUNA \& D. HIGGS. 2006. Effect of silicon on plant growth and mineral nutrition of maize grown under water-stress conditions. J. Plant Nutr. 29: 1469-1480.

KHOT, L.R., S. SANKARAN, J.M. MAJA, R. EHSANI, \& E.W. SCHUSTER. 2012. Applications of nanomaterials in agricultural production and crop protection: a review. Crop Prot. 35: 64-70. 
LAMBERS, H., F.S. CHAPIN \& T.L. PONS. 2008. Plant physiological ecology. New York, NY, USA: Springer-Verlag.

LEE, S. K., E.Y. SOHN, M. HAMAYUN, J.Y. YOON \& I.J. LEE. 2010. Effect of silicon on growth and salinity stress of soybean plant grown under hydroponic system. Agrofor. Syst. 80: 333-340.

LIANG, Y. C., Q. CHEN, Q. LIU, W.H. ZHANG \& R.X. DING. 2003. Exogenous silicon (Si) increases antioxidant enzyme activity and reduces lipid peroxidation in roots of salt-stressed barely (Hordeum vulgare L.). Plant. Physiol. Biochem. 160: 1157-64.

MA, J.F. \& E. TAKAHASHI. 2002. Soil, fertilizer, and plant silicon research in Japan. Elsevier.

MA, J. F. \& N. YAMAJI. 2006. Silicon uptake and accumulation in higher plants. Trends. Plant. Sci. 11: 392-397.

MA, J.F. 2004. Role of silicon in enhancing the resistance of plants to biotic and abiotic stresses. Soil. Sci. Plant. Nutr. 50: 11-18.

MAHAJAN, S. \& N. TUTEJA. 2005. Cold, salinity and drought stresses: an overview. Arch. Biochem. Biophys. 444: 139-158.

MATOH, T., P. KAIRUSMEE \& E. TAKAHASHI. 1986. Salt-induced damage to rice plants and alleviation effect of silicate. Soil. Sci. Plant. Nutr. 32: 295-304.

MCCUTCHAN, H. \& K.A. SHACKEL. 1992. Stemwater potential as a sensitive indicator of water stress in Prune trees (Prunus domestica L. cv. French). J. Am. Soc. Hortic. Sci.117: 607-611.

MEHRABANJOUBANI, P., A. ABDOLZADEH, H.R. SADEGHIPOUR \& M. AGHDASI. 2015. Silicon affects transcellular and apoplastic uptake of some nutrients in plants. Pedosphere 25: 192-201.

MONICA, R.C.\& R. CREMONINI. 2009. Nanoparticles and higher plants. Caryologia 62: 161-165.

NAIR, R., S.H. VARGHESE, B.G. NAIR, T. MAEKAWA, Y. YOSHIDA \& D.S. KUMAR. 2010. Nanoparticulate material delivery to plants. Plant. Sci.179: 154-163.

NARDINI, A., V. CASOLO, A. DAL BORGO, T. SAVI, B. STENNI, P. BERTONCIN, L. ZINI \& N.G. MCDOWELL. 2015. Rooting depth, water relations and non $\square$ structural carbohydrate dynamics in three woody angiosperms differentially affected by an extreme summer drought. Plant. Cell. Environ. 39: 618-627.

NIKOLAEVA, M.K., S.N. MAEVSKAYA, A.G. SHUGAEV \& N.G. BUKHOV. 2010. Effect of drought on chlorophyll content and antioxidant enzyme activities in leaves of three wheat cultivars varying in productivity. Russ. J. Plant Physiol. 57: 87-95.
ÖZÇELIK, B., U. KOCA, D.A. KAYA \& N. ŞEKEROĞLU. 2012. Evaluation of the in vitro bioactivities of Mahaleb cherry (Prunus mahaleb L.). Rom. Biotechnol. Lett.17: 7863-7872.

OZKUR, O., F. OZDEMIR, M. BOR \& I. TURKAN. 2009. Physiochemical and antioxidant responses of the perennial xerophyte Capparisovata Desf. to drought. Environ. Exp. Bot. 66: 487-492.

PEI, Z.F., D.F. MING, D. LIU, G.L. WAN, X.X. GENG, H.J. GONG \& W.J. ZHOU. 2010. Silicon improves the tolerance to water-deficit stress induced by polyethylene glycol in wheat (Triticum aestivum L.) seedlings. J. Plant. Growth. Regul. 29: 106-115.

PESSARAKLI, M. 2014. Handbook of plant and crop physiology. CRC Press.

RICHMOND, K.E. \& M. SUSSMAN. 2003. Got silicon? The non-essential beneficial plant nutrient. Curr. Opin. Plant. Biol. 6: 268-272.

SABAGHNIA, N. \& M. JANMOHAMMADI. 2015. Effect of nano-silicon particles application on salinity tolerance in early growth of some lentil genotypes. Ann. Univ. Mariae. 69: 39-55.

SACALA, E. 2009. Role of silicon in plant resistance to water stress. J .Elementol. 14: 619-630.

SEYYEDNEJAD, S. \& H. MOTAMEDI. 2010. A review on native medicinal plants in Khuzestan, Iran with antibacterial properties. Int. J. Immunopharmacol. 6: 551-560.

SHAMS, K.A. \& R. SCHMIDT. 2007. Lipid fraction constituents and evaluation of anti-anaphylactic activity of Prunus mahaleb 1. Kernels. Afr. J. Tradit. Complement. Altern. Med.4: 289-293.

SHEN, X., Y. ZHOU, L. DUAN, Z. LI, A.E. ENEJI \& J. LI. 2010. Silicon effects on photosynthesis and antioxidant parameters of soybean seedlings under drought and ultraviolet-B radiation. Plant. Physiol. Biochem. 167: 1248-1252.

SHI, Q., Z. BAO, Z. ZHU, Y. HE, Q. QIAN \& J. YU, 2005. Silicon-mediated alleviation of Mn toxicity in Cucumis sativus in relation to activities of superoxide dismutase and ascorbate peroxidase. Phytochemistry 66: 1551-1559.

SURIYAPRABHA, R., G. KARUNAKARAN, R. YUVAKKUMAR, V. RAJENDRAN \& $\mathrm{N}$. KANNAN. 2012. Silica nanoparticles for increased silica availability in maize (Zea mays L.) seeds under hydroponic conditions. Curr. Nanosci. 8: 902-908.

TOWETT, E.K., K.D. SHEPHERD \& B.L. DRAKE. 2016. Plant elemental composition and portable X-ray fluorescence ( $\mathrm{pXRF}$ ) spectroscopy: quantification under different analytical parameters. Xray. Spectrom.45: 117-124.

VACULIK, M., A. LUX, M. LUXOVA \& L. TANIMOTO. 2009. Silicon mitigates cadmium in- hibitory effects in young maize plants. Environ. Exp. Bot. 67: 52-58. 
WEI, C., Y. ZHANG, J. GUO, B. HAN, X. YANG \& J. YUAN. 2010. Effects of silica nanoparticles on growth and photosynthetic pigment contents of Scenedesmus obliquus. J Environ. Sci. (China). 22: $155-160$.

XIE, Z., R. SONG, H. SHAO, F. SONG, H. XU \& Y. LU. 2015. Silicon Improves Maize Photosynthesis in Saline-Alkaline Soils. Sci. World J. Article ID 245072.DOI 10.1155/2015/245072.

XU, C.X., Y.P. MA \& Y.L. LIU. 2015. Effects of silicon (Si) on growth, quality and ionic homeostasis of aloe under salt stress. S. African J. Bot. 98: 26-36.

YUVAKKUMAR, R., V. ELANGO, V. RAJENDRAN, N.S. KANNAN \& P. PRABU. 2011. Influence of nanosilica powder on the growth of maize crop (Zea mays L.). Int. J. Electron. 3: 180-190.

ZARAFSHAR, M., M. AKBARINIA, H. ASKARI, S.M. HOSSEINI, M. RAHAIE, D. STRUVE \& G.G. STRIKER. 2014. Morphological, physiological and biochemical responses to soil water deficit in seedlings of three populations of wild pear tree (Pyrus boisseriana). Biotechnol. Agron. Soc. Environ. 18: 353-366.

ZARAFSHAR, M., M. AKBARINIA, H. ASKARI, S.M. HOSSEINI, M. RAHAIE \& D. STRUVE. 2015. Toxicity assessment of sio $_{2}$ nanoparticles to pear seedlings. I.J.N.N.11: 13-22.

ZHANG, C., J.M. MOUTINHO-PEREIRA, C. CORREIA, J. COUTINHO, A. GONÇALVES, A. GUEDES \& J. GOMES-LARANJO. 2013. Foliar application of Sili-K® increases chestnut (Castanea spp.) growth and photosynthesis, simultaneously increasing susceptibility to water deficit. Plant Soil. 365: 211-225.
ZHANG, C., L. WANG, Q. NIE, W. ZHANG \& F. ZHANG. 2008. Long-term effects of exogenous silicon on cadmium translocation and toxicity in rice (Oryza sativa L.). Environ. Exp. Bot. 62: 300-307.

ZHAO, Y., D. ASPINALL \& L.G. PALEG. 1992. Protection of membrane integrity in Medicago saliva L. by glycinebetaine against the effects of freezing. J. Plant Physiol.140: 541-543.

ZLATEV, Z. \& F. C. LINDON. 2012. An overview ondrought induced changes in plant growth, water relations and photosynthesis. J. Food Agric. 24: 57-72.

ZUCCARINI, P. 2008. Effects of silicon on photosynthesis, water relations and nutrient uptake of Phaseolus vulgaris under $\mathrm{NaCl}$ stress. Biol. Plant. 52: $157-160$.

Recibido el 22 de agosto de 2017, aceptado el 19 de marzo de 2018. Editor: Federico Mollard. 
